\title{
SOSIALISASI KESEHATAN HEWAN KEPADA MASYARAKAT SECARA DARING
}

\section{Online Socialization Animal Health to the Community}

\section{Soedarmanto Indarjulianto*, Yanuartono Yanuartono, Slamet Raharjo, Alfarisa Nururrozi, Hastari Wuryastuty, Irkham Widiyono, Hary Purnamaningsih, Guntari Titik Mulyani, Ida Tjahajati, Sri Hartati, Yuriadi Yuriadi}

Fakultas Kedokteran Hewan, Universitas Gadjah Mada, Yogyakarta

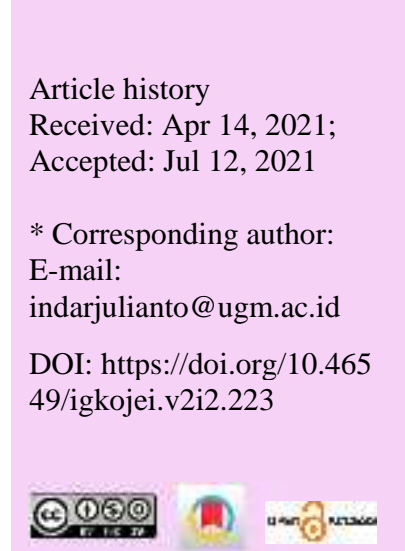

ABSTRACT

Various animal diseases are not always known to animal owners, therefore it is necessary to carry out socialization regarding this issue despite the ongoing COVID-19 outbreak. This community service aimed to provide animal health information to the community through online platforms. This activity was carried out in November 2020 utilizing the Cisco Webex platform. The results showed that 269 participants joined the event, consisting of 180 participants from Yogyakarta and 89 from outside Yogyakarta. The conclusion is that the online socialization of animal health has been successfully carried out and received an excellent response from the community.
\end{abstract}

Keywords: Animal health; Community service; Veterinary clinic

\begin{abstract}
ABSTRAK
Berbagai macam penyakit hewan tidak selalu diketahui oleh pemilik hewan, sehingga harus selalu disosialisasikan walaupun dalam kondisi wabah COVID19. Pengabdian kepada masyarakat (PKM) ini bertujuan memberikan informasi kesehatan hewan kepada masyarakat secara daring. Pengabdian dilakukan pada bulan Oktober sampai November 2020 secara daring menggunakan platform Cisco Webex. Hasil PKM menunjukkan bahwa sebanyak 269 calon peserta telah mengikuti sosialisasi, yang terdiri dari 180 berasal dari Yogyakarta dan 89 dari luar Yogyakarta. Berdasar hasil kegiatan ini, disimpulkan bahwa sosialisasi tentang kesehatan hewan secara daring berhasil dilaksanakan dan mendapat respon sangat bagus dari masyarakat.
\end{abstract}

Kata kunci: Kesehatan hewan; Pengabdian masyarakat; Klinik Hewan

\section{PENDAHULUAN}

Hewan merupakan bagian dari kehidupan manusia yang tidak dapat dipisahkan. Beberapa hewan dipelihara oleh manusia dengan tujuan diternakkan sebagai ternak produksi seperti sapi, ayam, kambing dan lain-lain. Hewan yang lain dipelihara oleh manusia sebagai hewan kesayangan ataupun teman hidup, seperti anjing, kucing, hamster dan lain sebagainya. Berbagai macam penyakit dapat diderita oleh hewan termasuk penyakit-penyakit yang disebabkan infeksi bakterial, viral, fungal maupun parasiter. Penyakit tersebut beberapa hanya diderita oleh hewan, tetapi ada juga yang mempunyai kemungkinan dapat menular ke manusia (Kruse et al., 2010; Soedarmanto et al., 2011; Yuningsih, 2012; Wandira et al., 2018; Yanuartono et al., 2020). 
Tanggung jawab pemilik dan pemelihara hewan memegang peranan yang sangat vital dalam menjaga supaya hewannya tetap sehat. Pengetahuan pemilik tentang kesehatan hewan, penyakit hewan, tindakan pertama ketika hewan sakit dan pencegahannya sangat diperlukan. Selain itu, pemilik dan/atau pemelihara hewan juga mempunyai risiko tertular beberapa penyakit dari hewan. Kurangnya pengetahuan tentang penyakit dapat menimbulkan kerugian yang sangat besar bagi pemilik/pemeliharanya baik secara finansial maupun non finansial. Oleh karena itu, seharusnya pemilik dan pemelihara hewan mengetahui berbagai macam penyakit dalam rangka untuk memelihara kesehatan hewannya dan sekaligus pemilik/pemeliharanya.

Sejak akhir 2019 telah terjadi wabah corona virus diseases 19 (COVID-19) yang disebabkan oleh virus yang tergolong dalam family coronavirus dan merupakan zoonosis yang berbahaya. Penelitian menyebutkan bahwa SARS ditransmisikan dari kucing luwak (civet cats) ke manusia dan MERS dari unta ke manusia, walaupun hewan yang menjadi sumber penularan COVID-19 ini masih belum diketahui (Kemenkes 2020a). Salah satu penularan COVID-19 yang sering dilaporkan adalah melalui droplet yang mengandung virus SARS-CoV-2 yang masuk ke dalam tubuh melalui hidung, mulut dan mata. Hal ini terjadi akibat kontak langsung dengan orang penderita COVID-19 baik yang menunjukkan gejala klinis maupun tidak (Bi et al., 2020; Kemenkes, 2020a). Oleh karena itu, dalam rangka menghindari penularan COVID-19 dari orang ke orang lain, maka semua kegiatan, termasuk pengabdian kepada masyarakat (PKM) perlu dirancang dalam bentuk tidak kontak langsung dengan orang.

Klinik Hewan Departemen Ilmu Penyakit Dalam FKH UGM merupakan Klinik Pendidikan yang melayani konsultasi, pemeriksaan dan terapi hewan, Berbagai macam klien/pemilik hewan yang telah memeriksakan hewannya di klinik ini, dengan berbagi tingkat pengalaman, pendidikan dan pengetahuan. Terbatasnya waktu kunjungan seringkali membuat kurang tersampaikannya informasi berkaitan dengan kesehatan hewan secara utuh. Adanya pandemi COVID-19 telah merubah pola dan metode pelaksanaan penyampaian informasi ataupun konsultasi berkaitan dengan kesehatan hewan. Tujuan PKM ini adalah untuk memberikan informasi tentang kesehatan hewan kepada masyarakat terutama pemelihara dan pecinta hewan secara daring.

\section{METODE}

Kegiatan PKM ini dilakukan dan dikoordinasikan di dan oleh Departemen Ilmu Penyakit Dalam FKH-UGM, periode waktu Oktober - Nopember 2020.

Pengabdian ini dilakukan dalam bentuk daring (online) seperti yang telah dilakukan Indarjulianto et al. (2021). Materi yang digunakan adalah komputer, telepon genggam beserta aksesoris audio visual, jaringan internet, tautan penyebaran info, bahan sosialisasi dan alat lain yang mendukung. Pengabdian kepada masyarakat sosialisasi kesehatan hewan ini diawali dengan pembuatan link dan 
Instagram (IG) dengan alamat ID: klinik.hewan.ugm yang sekaligus dipakai sebagai media komunikasi antara Departemen Ilmu Penyakit Dalam, FKH-UGM dengan masyarakat. Melalui IG tersebut diunggah gambar/informasi kegiatan dan pengumuman berkaitan dengan agenda sosialisasi kesehatan hewan (Gambar 1A). Kegiatan ini dilanjutkan dengan sosialisasi kesehatan hewan dalam bentuk tatap muka secara daring menggunakan platform Cisco Webex. Hasil pelaksanaan PKM dikoleksi dan dianalisis secara deskriptif.
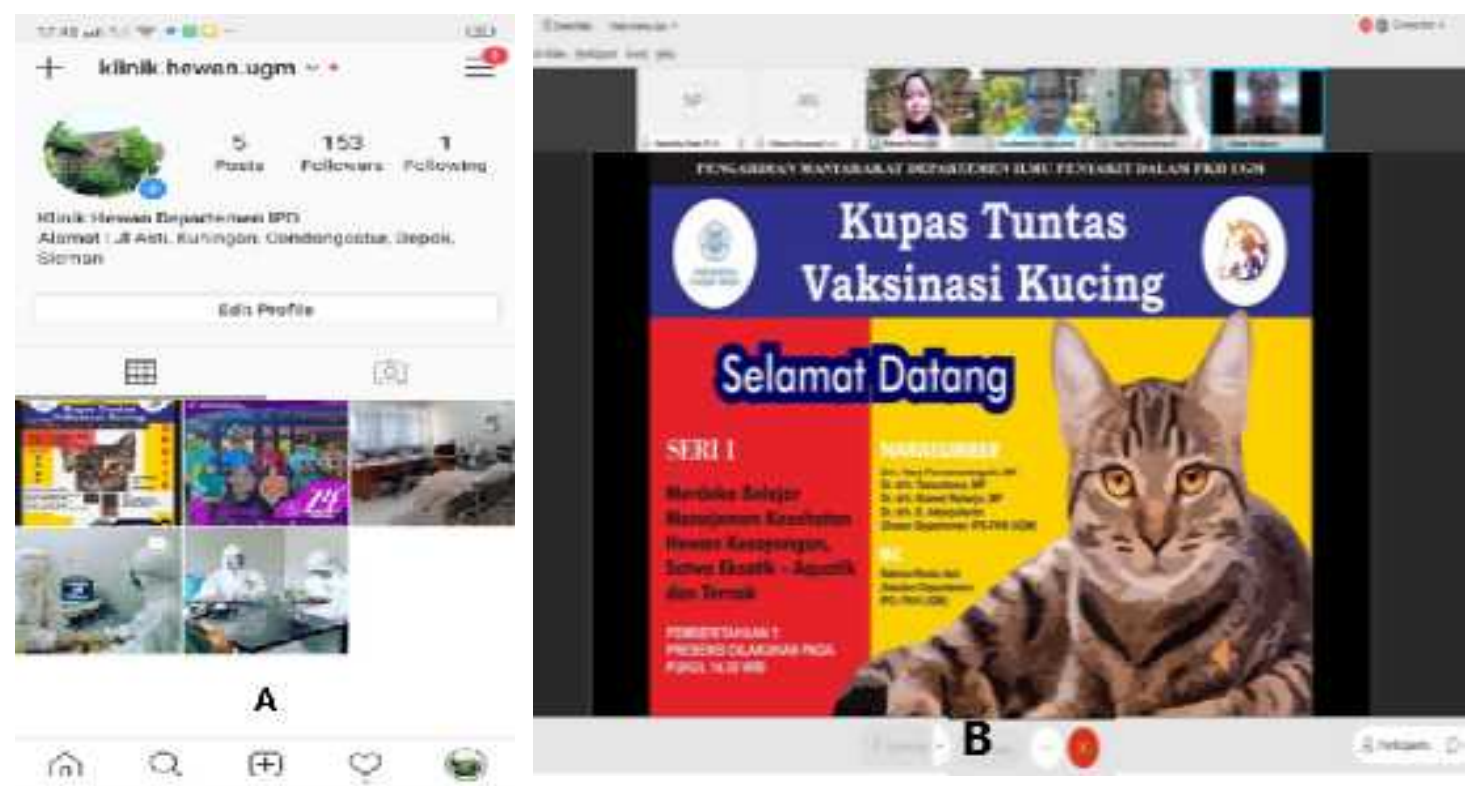

Gambar 1. (a) Flyer di dalam IG-Departemen IPD; (b) contoh screenshot pelaksanaan sosialisasi kesehatan Hewan secara daring.

\section{HASIL DAN PEMBAHASAN}

Hasil PKM sosialisasi kesehatan hewan dalam bentuk tatap muka secara daring menggunakan platform Cisco Webex berhasil dilaksanakan dan mendapatkan respon yang cukup bagus dari masyarakat (Gambar 1B). Peserta yang mendaftar sebanyak 269 yang berasal dari Daerah istimewa Yogyakarta sebanyak 180 dan yang dari luar DIY sebanyak 89 peserta (Gambar 2). Peserta yang mendaftar sudah melampaui target yang diharapkan sebelumnya, yaitu 250 peserta. Adanya peserta dari luar DIY dan terlampauinya target peserta tersebut menandakan bahwa banyak pemilik ataupun pemerhati hewan (kucing) yang masih memerlukan pengetahuan berkaitan dengan manajemen kesehatan pemeliharaan kucing. Selain itu, peserta sosialisasi juga aktif memanfaatkan kesempatan diskusi dengan narasumber berkaitan dengan cara pengobatan dan pencegahan penyakit pada kucing. Narasumber telah menjawab semua pertanyaan peserta secara runtut dan jelas dengan bahasa sederhana, sehingga peserta dapat mengerti dan menerima semua penjelasan yang telah diberikan oleh narasumber. Berbagai macam penyakit yang kemungkinan dapat menyerang pada hewan antara lain adalah gangguan sistem pencernaan, sistem urogenital, sistem pernafasan, penyakit kulit (Soedarmanto et al., 2011; Dewandaru et al., 2019; Nururrozi et al., 2020; Purnamaningsih et al., 
2020; Yanuartono et al., 2020). Selain penyakit hewan, pada PKM ini juga disampaikan pencegahan penularan penyakit kepada pemilik, terutama berkaitan dengan COVID-19 sesuai yang dianjurkan oleh Kementerian Kesehatan Republik Indonesia (Kemenkes RI) antara lain adalah a) Menggunakan alat pelindung diri berupa masker yang menutupi hidung dan mulut jika harus keluar rumah atau berinteraksi dengan orang lain, b) Menjaga jarak minimal 1 meter dengan orang lain dan c) Membersihkan tangan secara teratur dengan cuci tangan pakai sabun dan air mengalir selama 40-60 detik atau menggunakan cairan antiseptik berbasis alkohol (hand sanitizer) minimal 20-30 detik (Kemenkes 2020a; 2020b).

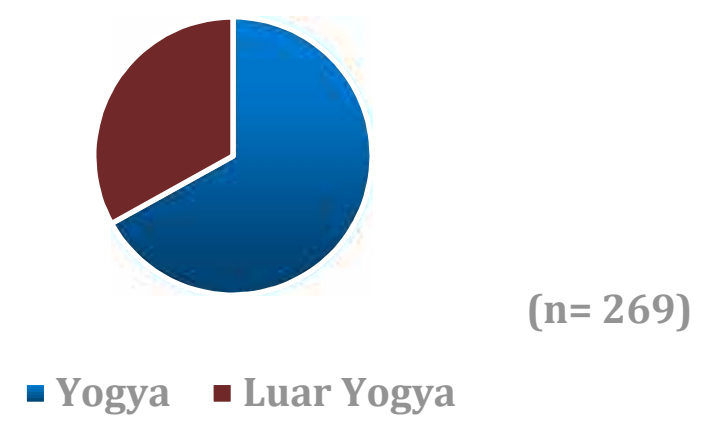

Gambar 2. Persentase jumlah peserta sosialisasi sistem daring dari dan luar Yogyakarta

Merebaknya wabah COVID-19 memaksa sistem penyampaian materi dan komunikasi, termasuk PKM harus menyesuaikan. Cara yang umum dilakukan adalah dengan sistem pembelajaran jarak jauh (daring/online). Sistem ini dianggap paling aman dan nyaman ketika diaplikasikan, karena tidak membutuhkan ruangan besar khusus untuk menampung para peserta. Penggunaan platform (aplikasi) biasanya dalam bentuk asynchronous sebagai e-learning untuk menyampaikan materi (email, Instagram dll.) dan secara langsung (synchronous) dalam pertemuan daring menggunakan video conference Google Meet, Zoom, Cisco Webex dll. (Rustaman, 2020).

Pada PKM ini, sebagian besar peserta sudah familiar dengan aplikasi Cisco Webex, tetapi masih ada beberapa peserta yang kesulitan bergabung, bahkan sampai akhir masih ada 3 orang yang tidak dapat bergabung. Hal ini kemungkinan masih ada orang yang belum terbiasa mengikuti webinar. Penggunaan sistem daring ini sebetulnya sudah banyak dilakukan dengan menggunakan berbagai macam bentuk aplikasi, terutama di dunia pendidikan (Pradja dan Baist, 2019; Taufiqurrahman, 2020). Penggunaan aplikasi daring (Edmodo), Video conference (Google Meet) dan sosial media Instagram sangat membantu mahasiswa dalam menjalankan perkuliahan dan praktikum (Rustaman, 2020). Oleh karena itu, kedepan sangat diperlukan sosialisasi sistem pembelajaran/komunikasi daring ini kepada masyarakat luar, selain di dunia pendidikan dan pemerintahan. 


\section{KESIMPULAN}

Berdasar hasil kegiatan ini, disimpulkan bahwa sosialisasi tentang kesehatan hewan secara daring berhasil dilaksanakan dan mendapat respon sangat bagus dari masyarakat. Kegiatan sosialisasi secara daring merupakan metode alternatif yang tepat ketika kegiatan luring tidak memungkinkan direalisasikan karena adanya pandemi COVID-19.

\section{UCAPAN TERIMA KASIH}

Terimakasih kepada Departemen IPD dan FKH UGM yang telah memberikan fasilitas laboratorium dan pendanaan dengan nomor kontrak 1376/UN1/FKH/HK4/2020.

\section{DAFTAR PUSTAKA}

Bi Q, Wu Y, Mei S, Ye C, Zou X, Zhang Z, Liu X, Wei L,Truelove SA, Zhang T, Gao W, Cheng C, Tang X, Wu X, Wu Y, Sun B, Huang S, Sun Y, Zhang J, Ma T, Lessler J, dan Feng T. 2020. Epidemiology and transmission of COVID-19 in 391 cases and 1286 of their close contacts in Shenzhen, China: a retrospective cohort study. Lancet Infect Dis. 20: 911-919.

Dewandaru R., Indarjulianto S, Yanuartono Y, Nururrozi A, Purnamaningsih H, dan Rusmihayati. 2019. Diare Disebabkan Infeksi Escherichia coli pada Anjing. JIPVET. 9(2): 38- 43.

Indarjulianto S, Widiyono I, Sarmin, dan Airin CM. 2021. Pelatihan Penggunaan Alat Penghalus Kotoran Ternak di Kelompok Ternak Sidomaju Bantul Yogyakarta. 2021. IGKOJEI: Jurnal Pengabdian Masyarakat. 2(1): 32 - 37. DOI: https://doi.org/ 10.46549/igkojei.v2i1.168

Kruse BD, Unterer S, Horlacher K, Sauter-Louis C, Hartman K. 2010. Prognostic Factors in cats with feline panleukopenia. J of Veterinary Internal Medicine. 24: 1272-1276.

Kemenkes, Kementrian Kesehatan Republik Indonesia. 2020a. Pedoman Pencegaha dan Pengendalian COVID-19. https://covid19.go.id/storage/app/media/Protokol/REV05_Pedoman_P2_COVID-19_13_Juli_2020.pdf (download 03-11-2020).

Kemenkes, Kemenrian Kesehatan Republik Indonesia. 2020b. Standar APD (Alat Pelindung Diri) untuk Penanganan COVID-19 di Indonesia. https://covid19.go.id/storage/app/media/Materi\%20Edukasi/standar-apd-revisi-3.pdf. (download 03-11-2020).

Nururrozi A, Indarjulianto S, Yanuartono, Hartati S, Wuryastuti H, Yuriadi, Widiyono I, Tjahajati I, Purnamaningsih H, Mulyati GT, dan Raharjo S. 2020. Prevalence And Associated Risk Factor of Feline Lower Urinary Tract Disease in Cats Attending Primary Care Veterinary Practices in Yogyakarta. Di Prosiding International Symposium AJIVE.

Purnamaningsih H, Indarjulianto S, Yanuartono Y., Nururrozi A, Widiyono I, dan Rusmihayati R. 2020. Gambaran Leukosit Kucing Penderita Feline Panleukopenia. JSV. 38 (2): 121-125.

Pradja BP, dan Baist A. 2019. Analisis Kualitatif Penggunaan Microsoft Teams Dalam Pembelajaran Kolaboratif Daring. Di Prosiding SENATIK 4. Universitas PGRI, Semarang.

Rustaman AH. 2020. Efektivitas Penggunaan Aplikasi Daring, Video Conference Dan Sosial Media Pada Mata Kuliah Komputer Grafis 1 Di Masa Pandemi Covid-19. Jurnal Ilmu Sosial dan Pendidikan. 4(3): 557-562.

Soedarmanto I, Kanbar T, Ülbegi-Mohyla H, Hijazin M, Alber J, Lämmler C, Akineden O, Weiss W, Moritz A, dan Zschöck M. 2011. Genetic relatedness of methicillin-resistant Staphylococcus pseudintermedius (MRSP) isolated from a dog and the dog owner. Res. Vet. Sci. 91, Pp e-25-e27.

Taufiqurrahman M. 2020. Perkuliahan daring mata kuliah Ilmu Pendidikan Islam pada masa darurat Covid-19. Ta'dibuna: Jurnal Pendidikan Islam. 9(2): 213-224.

Yanuartono, Indarjulianto S, Nururrozi A, Raharjo S, dan Purnamaningsih H. 2020. Penggunaan Antiparasit Ivermectin pada Ternak: Antara Manfaat dan Risiko. Jurnal Sain Peternakan 
Indonesia 15(1): 110-123.

Yuningsih. 2012. "Keracunan Sianida pada Hewan dan Upaya Pencegahannya". Jurnal Litbang Pertanian. 31 (1): $21-26$

Wandira A, Supriadi, dan Permatasari FD. 2018. Prevalensi Scabies pada Kambing di Desa Rembitan Kecamatan Pujut Kabupaten Lombok Tengah. Jurnal Sangkareang Mataram 4(3): 46-50. 